University of South Florida

DIGITAL COMMONS

Digital Commons @ University of

@ UNIVERSITY OF SOUTH FLORIDA

South Florida

Educational Leadership and Policy Studies Faculty Publications

2006

\title{
What are We Tripping On?: Transgressing the Fault Lines in Research on the Preparation of Multicultural Educators
}

\author{
Carl A. Grant \\ University of Wisconsin - Madison, grant@education.wisc.edu \\ Vonzell Agosto \\ University of Wisconsin - Madison, vagosto@usf.edu
}

Follow this and additional works at: https://digitalcommons.usf.edu/els_facpub

Part of the Curriculum and Instruction Commons, Curriculum and Social Inquiry Commons,

Educational Administration and Supervision Commons, Education Policy Commons, Race, Ethnicity and

Post-Colonial Studies Commons, and the Teacher Education and Professional Development Commons

\section{Scholar Commons Citation}

Grant, Carl A. and Agosto, Vonzell, "What are We Tripping On?: Transgressing the Fault Lines in Research on the Preparation of Multicultural Educators" (2006). Educational Leadership and Policy Studies Faculty Publications. 6.

https://digitalcommons.usf.edu/els_facpub/6

This Book Chapter is brought to you for free and open access by Digital Commons @ University of South Florida. It has been accepted for inclusion in Educational Leadership and Policy Studies Faculty Publications by an authorized administrator of Digital Commons @ University of South Florida. For more information, please contact digitalcommons@usf.edu. 


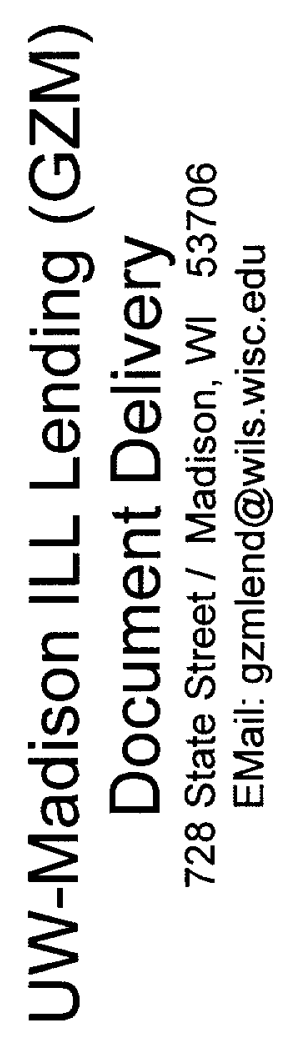

Journal Title: Sage Handbook for Research in Education: Engaging Ideas and Enriching Inquiry

Volume:

Issue:

Month/Year: 2006

Pages: $95-115$

Article Author: Grant \& Agosto

Article Title: What are we tripping on?

Transgressing the fault lines in research in the preparation

OCLC Number:

ISSN/ISBN Number:
Location: cimc

Call \#: LB1028 S14 2006

Request Date: 10/10/2008 09:41:59

AM

Not Wanted After:

Patron: VONZELL AGOSTO

Patron

EMail:VAGOSTO@WISC.EDU

Notes:

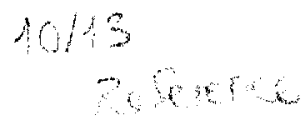

\section{Odyssey}




\title{
What Are We Tripping On?
}

\section{Transgressing the Fault Lines in Research on the Preparation of Multicultural Educators}

\author{
Carl A. Grant \\ University of Wisconsin-Madison \\ VonZell Agosto \\ University of Wisconsin-Madison
}

$\mathrm{A}$ n enduring problem in multicultural education over the past 50 years has been the following: How can teacher education programs prepare, train, and/or influence preservice teachers to teach all students effectively? Or, put more simply, how do we prepare preservice teachers to become multicultural educators? The purpose of this chapter is to discuss some of the research in multicultural teacher education that speaks to and, in so doing, participates in the life of this enduring problem. The guiding question from which we work and invite readers to consider is as follows: In what direction might other rationales and subsequent lines of inquiry lead the research in multicultural teacher education? Although we pose many questions throughout this essay, all questions lead us back to this guiding question.

The questions we raise in this chapter have come to us through our experiences in teaching college freshmen, our informal conversations with teacher educators, and our review of academic and popular culture books and movies. These experiences, conversations, and reviews continue to present a traditional teacher who is not a multicultural educator. The implications of the absence of the multicultural educator are evident through the education-related practices and expectations that our students exhibit and do not exhibit as well as in preservice teachers' resistance to multicultural education (as reported by multicultural teacher educators).

We contend that "multicultural" does not mean "people of color," that is, all individuals except white people. It is illogical to think that improving the education system so that it well educates more students across a broader spectrum of differences can happen with an approach designed and employed solely by or for people of color when the majority of students, teachers, administrators, and education policymakers are white, not people of color. At some level, this misconception-the 
absences, the inequities, and our concerns about the quality of education overall -challenge and compel us to ask and respond to the following question: For whom is multicultural education not necessary?

\section{The Widespread NeEd For Multicultural Education}

Multicultural teacher educators tell us that many preservice teachers plan to return to their racially homogeneous middle- and upper-middleclass communities where students graduate from high school and attend college. Because of these plans, preservice teachers often argue that multicultural education is unnecessary for them or the students in their communities. In other words, preservice teachers suggest that multicultural education is not applicable to their communities now or in the future and, therefore, holds no value for them.

How do we respond to preservice teachers who think that the education system is adequate, that changing it is (and forever will be) outside their realm of influence, that the qualities and borders that frame their communities are fixed, and that what they do in their classes will not have consequences that reverberate across distance and time? Responding to these comments and questions is an expectation we have of multicultural teacher educators. We suggest that these classroom-based interactions, alongside research, are a crucial component in the development of multicultural teacher education.

Because this problem (among others) has not been resolved, many students fail to receive a quality education. A quality education would prepare students to compete for high-quality career opportunities, enjoy and provide a social and leisure lifestyle, contribute to the welfare of the global community, and recognize-as well as combat-the forces (e.g., institutions, systems, organizations, traditions) that forestall the equitable distribution and attainment of these opportunities. The education system consistently fails to provide a quality education, especially for particular groups of students (e.g., students who are economically disadvantaged, (dis)abled, members of particular racial groups, members of particular ethnic groups,
English- (as a second) language learners, and/or recent immigrants). This list is not exhaustive or static. Often excluded from this list of students who do not receive a quality education are those who do receive adequate resources and may or may not fall into one of the aforementioned historically marginalized groups-the "traditional" students. These traditional students tend to fall within the norms of the majority population's expectations in terms of compliance, unquestioning acceptance, promptness, attentiveness, health, attractiveness, interests, confidence, ability to prioritize school-related activities (not necessarily education), and reliance on the support of others who have successfully navigated the system. These students tend to be white and middle or upper class.

In addition, traditional students tend to create and meet a traditional expectation within this traditional system (e.g., remain seated, ask questions related to the subject matter, do not challenge the teacher's intellectual or ministerial authority, complete assignments promptly, seek permission). These traditional students, both current and former, reinforce the normative expectations that make the education system (for better and/or worse) resistant to rapid and sweeping change. Given the slow pace of systemwide educational change, multicultural education is in its infancy. However, the critical point here is that traditional students are, for the most part, neglected in the discourse around quality education, the rationales for multicultural (teacher) education, and the research. Many of these students become leaders (e.g., executives, deans in schools of education) who perpetuate the system because it appears to have served them well when measured by a narrow gauge of self-sufficiency. We cannot afford to neglect traditional students in our conception, practice, or research in multicultural (teacher) education. Traditional students deserve a quality education as well.

In part as a reaction to the failure of the education system in the United States of (North) America (not Mexico) to educate well its diverse student populations, teacher educators and others since the 1970s have conducted research to inform teacher education programs about how best to prepare teachers to teach students across diverse backgrounds. According 
to Grant and Zozakiewicz (1995), "Our responsibility is to prepare teachers who can participate in a systemic change effort to help school become the 'great equalizer' and proponent of equity for all students" (p. 272). That these inequities continue alongside newly created ones, despite the rising public attention and efforts of many to further multicultural education, begs us to ask the question: What are we tripping on?

\section{Overview of The Chapter}

In this chapter, we identify unaddressed questions and analyze research studies in multicultural teacher education to examine how current, neglected, and/or seldom interrogated rationales, lines of inquiry, and practices in research and teaching operate as fault lines or smaller ruptures. In addition, we offer suggestions for future research that builds on the lines of inquiry that studies in multicultural teacher education inspire. We use the term "fault lines" to demonstrate the complexity, tension, and urgency of the problem. Some of the fault lines that the research in multicultural teacher education reveals are embedded in the field, whereas others are superficial, at the level of practice, as isolated and individual actions. We are mainly concerned with the recurring fault lines, whether embedded or superficial. The research in the field provides a lens that captures and makes evident the fault lines that are visible and those that are not. These fault lines operate as breaks, or brakes, in the field and hinder the efforts to prepare and expand the multicultural teaching force. We hope to reveal the fault lines in the field so that workers (as researchers, teacher educators, or preservice teachers) might transgress them and continue on the path toward "producing" a greater number of multicultural educators.

We limit this discussion to researchers, teacher educators, and (preservice) teachers. We draw from conceptual, theoretical, and empirical research in the fields of teacher education and multicultural education. Transgressive, democratic, or emancipatory education, for example, have goals that overlap with multicultural education. However, we limit our survey to research in which the authors explicitly position the research within the field (in connection with multicultural education or diversity education as noted in the titles, abstracts, keywords, or introductions) and thereby directly support multicultural (teacher) education as a field of inquiry.

We recognize that our decision to use this approach limits the scope, and thus the actual representation, of those who identify as multicultural educators. Likewise, the decision of researchers to include or exclude the term "multicultural," in particular, has implications for the future of the field and its associated outcomes. However, we can only speculate about whether the absence of the term or its unprivileged position in a research article is a minor fault line that, over time, quietly serves to dismantle the field.

\section{CONCEPTS In CONTEXT: Diversity, Multiculturalism, and Social Justice}

Together, multiculturalism and social justice serve as the conceptual lenses we use to discuss the research and scholarship on preparing multicultural educators to teach across a diversity of student populations. Diversity, as it is commonly expressed and defined in and outside of the academic community, provides the context for our discussion. The following statements situate history, inclusiveness, and the current significance of diversity to the question of how to prepare preservice teachers to become multicultural educators. Parrillo (1996) argues, "Diversity in America has been an ongoing social reality that has gone through many changes in the United States, not since its inception as a nation but even in its primeval colonial cradle" (p. 5). Macedo (2000) states, "Diversity embodies an insistence that no one should be excluded from the American dream of equal justice based upon arbitrary and irrelevant differences of skin color, gender ethnicity, or sexual orientation" (p. 2). In addition, Macedo claims,

Diversity is the great issue of our time: nationalism, religious sectarianism; a heightened conscious of gender, race, and ethnicity; a greater 
assertiveness with respect to sexual orientations; and a reassertion of religious voices in the public square are but a few of the forms of particularity that stubbornly refuse to yield to individualism and cosmopolitanism. (p. 1)

Sacks (2002) suggests that diversity, as an essential aspect of this world, expands our possibilities:

The world is not a simple machine. It is a complex, interactive ecology in which diversitybiological, personal, cultural, and religious-is of the essence. Any proposed reduction of that diversity through the many forms of fundamentalism that exist today-market, scientific, or religious - would result in a diminution of the rich texture of our sacred life, a potentially disastrous narrowing of the horizons of possibility. (p. 22)

The preceding statements by Parrillo, Macedo, and Sacks help us to understand and appreciate the enduring significance of the question of how to prepare preservice teachers to become multicultural educators as well as why the question has yet to receive a satisfactory response. Currently, diversity is socially palatable as a signifier of difference for those who embrace individuality, whereas multiculturalism (when simplified to mean many cultures) alludes to a mixing of people, which some still find alarming.

Whether understood in its narrowest or broadest sense, multiculturalism stands in opposition to individualism. Individualism supports and promotes a sense of nationalism that ignores the multiplicity of its people's voices and the complexity of their dialogues, which together in tension continue to shape the United States. "The discourse of multiculturalism represents, in part, the emergence of new voices that have generally been excluded from the histories that have defined our national identity" (Giroux, 1996, p. 198). García (1982), Grant (1977), and Frazier (1977) all maintain that multicultural education is "a concept, a framework, a way of thinking, a philosophical viewpoint, a value orientation, and a criteria [sic] for making decisions that better serve the educational needs of culturally diverse student populations" (cited in Banks \& Banks, 1995, pp. 27-28). Although culturally diverse student populations may require more immediate and intensive use of multicultural practices, multicultural education is not an approach, a concept, a framework, an orientation, a criterion, a viewpoint, and/or a way of thinking that exclusively serves the needs of culturally diverse student populations.

The education literature includes different conceptual meanings of multicultural education. Definitions of multicultural education vary widely with respect to content, method, procedure, and referent group orientation. Nevertheless, some multicultural scholars are in close agreement when defining multicultural education. Banks (1993) argues, "Multicultural education is an idea, an educational reform movement, and a process whose major goal is to change the structure of educational institutions" (p. 7). We suggest that multicultural education better serves the needs of students than does education that does not consider the factors that make attributes or positions (e.g., sexuality, ethnicity, language) matter or not matter in ways that shape and define our conditions and, therefore, our lives.

Social justice, as defined by Young (1990), is "the elimination of institutionalized domination and oppression" (p. 15). Social justice goes beyond the mere distribution of benefits (i.e., income and wealth) among the members of a society to an examination of institutional and social relations. It involves the degree to which a society supports the elements necessary for a good life. These general elements are (a) "developing and exercising one's capacities and expressing one's experience" and (b) "participating in determining one's action" (p. 37). Social justice, then, involves the promotion of values of self-development and self-determination for everyone. García (1997) states, "Justice demands equality and fairness in all private transactions, wages, and property ownership, as well as equal opportunity for all to participate in the public benefits generated by society as a whole such as social security, health care, and education" (p. 247).

Cochran-Smith, Davis, and Fries (2004) connect diversity, multiculturalism, and social justice with teacher education, teacher educators, research, and policy as follows: 
The strikingly different racial, cultural, and linguistic profiles of the nation's student and teaching populations, coupled with continuing disparities among racial and cultural groups in school achievement and completion rates, poverty levels, and opportunities to learn from qualified teachers, have been highlighted for some time now as a pressing - if not the most pressingissue for teacher preparation research, practice, and policy. (p. 931)

\section{IDENTIFYING AND EXAMINING}

FAULT LiNES IN RESEARCH: Rationales, Program Components, and Research Practices

Our purpose here is not to provide a traditional review of the multicultural research literature on teacher education and teacher educators. Instead, we use research literature to illuminate problems in research efforts aimed at addressing this question: How do we prepare multicultural educators? Our discussion does not concentrate on methodological or conceptual issues, nor does it address concerns with the reviews of the literature. Instead, we raise questions to help researchers better capture the complexity of the problems associated with preparing multicultural teacher educators-a complexity that is sometimes overlooked as a result of how researchers explore the topic and report findings.

Even the endeavor of co-authoring often results in the presentation of a unified voice. Rather than completely suppress the moments in which we merged, with difficulty, our ideas or styles into a single statement, we acknowledge that this essay is the result of a complex conversation in which we engage as co-authoring agents and engage with each other, researchers, educators, and the field of multicultural teacher education as a whole.

"How do we prepare multicultural educators?" is a question that takes into account several areas of inquiry: rationales for multicultural education, multicultural teacher education programs, the demographic profile of those who make up the cadre of multicultural teacher educators, and multicultural practices in education and research. Within each of these areas are fault lines.

\section{Fault Lines in Rationales: Increasing Diversity, Reducing Diversity to Race/Ethnicity, and Conflating Race and Ethnicity}

There are several major fault lines in the primary rationale used to argue for multicultural teacher education: increasing diversity, reducing diversity to race/ethnicity, and conflating race and ethnicity. Although several rationales supporting the need for multicultural teachers are present throughout the research (e.g., moral, civic), the one that dominates the research is the demographic rationale. Where a research article offers more than one rationale, it is the demographic rationale, rather than another rationale, that appears in the opening paragraph and thus frames the article. In dominating, the demographic rationale obscures the need to provide other rationales, especially those that would suggest that the need for multicultural educators is timeless. What rationale will we offer once the demographic shift occurs? Does the demographic rationale speak to teachers' desires for self in society improvement as well as to their desires for self in society preservation?

Increasing Diversity. The primary rationale in most of the educational literature is a demographic rationale, shift, trend, or imperative suggesting that the numbers of multicultural educators should expand because the student body is becoming more diverse. U.S. census data are used to argue that the increased immigration of students from Asian countries and the increased school enrollment of Latino students increase the need for multicultural education. This rationale positions diversity as a deficit (Ladson-Billings, 1999), whereby diversity is something with which we must contend-a challenge. Pearl (1997) reminds us, "Efforts such as multicultural education and equity pedagogy are used to interrupt notions of deficit thinking but are often 'contaminated by other forms of deficit thinking"" (cited in Brandon, 2003, p. 39).

An alternate line of reasoning might suggest that multicultural teacher education is necessary to expand the repertoire of teacher abilities and transform the teaching force from monolingual/ monocultural to a force of multicultural 
performers who communicate multilingually depending on the students before them. Rather than speak of the demographic shift as something new and something to fear, we might welcome its potential to foster educational reform and broaden our vision of the demographic profile. What does the current and predicted demographic trend mean for educational practice, and what preparation will benefit the incoming generation of teachers? Can this demographic shift challenge researchers to expand the narrow focus on ethnic and/or racial demographic categories as the predominant markers of diversity?

Reducing Diversity to Race or Ethnicity. The literature claims that with the increase in student diversity and the homogeneity of the teaching force, there is a racial and/or ethnic mismatch between students and teachers (Fuller, 1992; Gay, Dingus, \& Jackson, 2003; Grant \& Millar, 1992; Growe, Schmersahl, Perry, \& Henry, 2002; Martin, 1995; Oliva \& Staudt, 2003). Much of multicultural research in teacher education argues that one of the reasons for the failure of public education to advance some groups of students (e.g., poor students and students of color from particular racial and/or ethnic groups) through secondary education and into higher education as well as it advances white middle-class students stems from the differences between students and their teachers. More generally, researchers attribute the failure to differences between students' and teachers' experiences, expectations of students, and norms associated with their racial and/or ethnic identities (e.g., American Association of Colleges for Teacher Education [AACTE], 1990; LadsonBillings, 2001).

The multicultural literature argues that multicultural teacher education goes beyond matching teachers' and students' (pre)existing sociocultural experiences. It echoes the position of Gollnick (1992), Villegas (1991), and Zeichner and Hoeft (1996) that all teachers, regardless of their experiences or their students' experiences, must be concerned with the challenge of intercultural communication. If this is so, then must not educators and researchers begin to participate in and learn from heterogeneous communities because they (given the increased recognition of diversity) will most closely resemble the contexts in which students and teachers will become educated? Should a rationale for building a diverse teaching force broaden to consider global demographic trends, including their deeper impact on values, ideas, and daily practices and how they intersect in the lives of students?

Montecinos (2004) states, "Current efforts to diversify the teaching force have concentrated on increasing ethnic diversity as opposed to social class or gender diversity, although the teaching force is also homogeneous on those aspects" (p. 168). For example, the National Council for Accreditation of Teacher Educators (NCATE, 2002) reports that minority teachers comprise less than $15 \%$ of the teaching force. The term "minority" is generally used to refer to ethnic and/or racial composition. Thus, other social markers (e.g., social class) are omitted. Also, although race and ethnicity are often at the center of many studies, very few studies include or reveal participants' bi- or multiracial/ethnic identity alone or in combination with other characteristics such as generational and current immigrant status (e.g., Ladson-Billings \& Henry, 1990; Ríos \& Montecinos, 1999). If we take into account ability, class, gender, language, religion, sexuality, and/or ideology, for example, the teaching force is less diverse than most studies in the field of teacher education purport. Should the focus on race and/or ethnicity continue? The research reports conflicting findings regarding the significance of race and/or ethnicity in teachers' ability and willingness to work well across the student population.

Conflating Race and Ethnicity. It may be noted in passing that many research studies in multicultural education conjoin and conflate race and ethnicity so that they operate as one vein of the demographic shift. A broader demographic rationale recognizes that race and ethnicity are often two very different categories that become more or less (in)significant across time and space and in relation to others. As such, race and/or ethnicity are not always the most salient or prominent aspects that must be considered. Factors such as class and nationality can obfuscate experiences that, in part, become manifest in response to one's racial and/or ethnic identity 
or position and, thus, fracture the common experience that race and/or ethnicity alone might have engendered. In addition, race and/or ethnicity generate a multiplicity of experiences, needs, and desires to which the education system is increasingly expected to respond.

Ríos and Montecinos (1999) state, "There is evidence suggesting that teacher candidates' ethnicity does matter, with teachers from ethnic groups of color being more likely to endorse approaches to multicultural education with equity and social justice at [their] core" (cited in Montecinos, 2004, p. 173). In addition, Villegas and Clewell (1998) claim that the strengths that teachers of color may bring to the classroom are their knowledge about social/ethnic minority communities and insight into the minority experience in the United States. Gay and colleagues (2003) report that teachers of color are needed to serve as role models and for mainstream students to learn about ethnic, racial, and cultural diversity. Yet in a classic study, Risk (1970/2000) reports how schools help to reinforce the class structure of society as black middle-class teachers stereotype black workingclass kindergarteners by placing them in reading groups that reflect their social classes. These studies contend that teachers' racial and/or ethnic identity does not guarantee the willingness or ability to work successfully with particular racial and/or ethnic groups of students (Ríos \& Montecinos, 1999). Also, Zeichner and colleagues (1998) contend that cultural knowledge is insufficient in itself and that such knowledge "will have limited payoff unless teachers can translate these insights into pedagogical practices" (p. 167). Investigating where teachers prefer to work, a 1990 study conducted by the AACTE asked preservice teachers whether they preferred to teach in a "majority" (predominantly white) setting or a "minority" (predominantly non-white) setting. The AACTE reports that $80 \%$ of blacks, whites, and Latinos, as well as $60 \%$ of Asians, indicated a preference for a majority setting (Gomez, 1993). Along another line of inquiry related to race and/or ethnicity, Grant and Secada (1990) ask, "Is there empirical evidence that having teachers of color will positively affect the achievement scores of students of color and help white students to have a positive attitude toward students of color?" (p. 406). Much of this literature ignores other studies reporting that the mismatch between students' and teachers' race and/or ethnicity might not be a barrier to academic achievement.

The literature also ignores students of color who are becoming teachers. On analyzing 35 published studies pertaining to multicultural teacher education courses in the United States, Montecinos (2004) warns of the scant attention afforded to teachers of color in the research literature. This omission is especially problematic for cultural groups and communities with varied ethnicities and racial identities because the omission does not make visible the nuances of common experiences, beliefs, worldviews, and rituals that inform teaching and learning behaviors.

Some of the salience of the demographic rationale is lost when researchers neglect to disclose the ethnicities of their research participants. Our suggestion is that multicultural education researchers should further disaggregate data according to class, ability, gender, sexual orientation, and other social markers to reveal aspects of diversity. Disaggregating data allows readers to consider how these aspects operate individually or through their intersections to situate and motivate, for example, students and teachers. Disaggregating data also allows for multiple readings and alternate lines of inquiry or reasoning. Narrowing diversity to race and/or ethnicity and gender, for example, allows other aspects of diversity to remain unexamined. Whether teachers' race, social class background, gender, and other social markers significantly contribute to their success in teaching students is a question very much in need of future research.

According to an analysis of research in multicultural education published between 1990 and 2001, Grant, Elsbree, and Fondrie (2004) report that "little research exists in the areas of sexuality, multiethnicity, and religion" (p. 7). Educators often teach students who might not share the same category of sexual identity. Students may identify as straight, lesbian, gay, bisexual, transgendered, queer, intersex, or pansexual (those for whom gender is not the predominant factor that determines the possibility for intimate relations or partnerships). In addition, these same students may identify as 
members of one or none of these current categories of sexuality, have a fluid sexuality, be questioning their sexual identity, or be in the initial stages of sexual identity formation. As more elementary and middle school students participate in gay-straight alliances and then enter secondary school better prepared to engage in discourse around issues of sexuality, it is likely that their expectations of and demands on teachers will shift. The research on sexuality in multicultural education, and in teacher education in general, is scarce. If the question of whether students' socioeconomic status, ethnicity, and/or language is a critical factor in determining their experiences and relationships with educators, as well as their performance in learning contexts, then should not research also consider whether students' sexuality may also be a critical factor in influencing students' education experience?

\section{Fault Lines in the Program Components: Time, Out-of-School Structures, and Teaching Practices}

There are several fault lines related to the research on programs that prepare multicultural teachers. These fault lines in the research range from the amount of time invested in the preparation of teachers to the attention that preparation programs give to informing students about the effect of out-of-school structures on their teaching and teaching practices. Most education programs claim that they can socialize teachers for cultural diversity (Zeichner \& Hoeft, 1996). Can this socialization really take place? Is time a factor? The educational research literature does not provide a definitive answer. In fact, the research base on this question is thin, and concern about this as a major research question is at best modest.

Time. There is no agreement over the amount of time needed to prepare highly qualified teachers. What we know from the research literature is that the amount of time it takes, and the extent to which teacher education programs can socialize or (re)socialize teachers' practices and attitudes, varies. Research evidence notwithstanding, most traditional university teacher education programs invest 2 years toward preparing teachers. Some programs, such as Teach for America and Troops to Teachers, contend that spending 2 to 3 years in a teacher preparation program is unnecessary and place their teachers in classrooms after approximately 5 weeks of preparation. Some states (e.g., California) contend that teachers can be prepared in a year once they earn a bachelor's degree.

Currently, there is a lack of attention given to the idea that teacher education programs are needing to re(socialize) students (i.e., prospective teachers) who have spent several prior years envisioning and fashioning their own model of a "teacher." A study of Latina/Latino (Latina/o) high school students in Texas who were participating in a preservice model for recruiting Latina/o students into teaching reports that more than $60 \%$ of the students in this program decided to become teachers before 20 years of age (Oliva \& Staudt, 2003). These students, as well as other students who follow the more traditional pathways into teaching ( 2 years of liberal arts before entering a school of education), enter programs with preconceived ideas about the "teachers" they wish to become.

But what perceptions do students have about the teachers they wish to become? How do these perceptions influence their attitudes and behaviors toward teaching students from culturally diverse student population groups? Gomez and Tabachnick (1992) report that changing teachers' perspectives on diverse "others" is a long and labor-intensive process (cited in Gomez, 1993).

The low impact of the teacher preparation program on professional learning, including changing preservice teachers' implicit theories about teaching and being a teacher, is well documented (Flores, 2001; Pataniczek \& Isaacson, 1981; Zeichner \& Gore, 1990). Flores (2001) studied first-year teachers and concluded,

Initial teacher education had a weak impact in determining beginning teachers' professional behavior. The teachers in the study referred to the gap between theory and practice and to the inadequate preparation for coping with the daily problems of the school and the classroom, especially as it [sic] regards interaction with students. (p. 138) 
McDiarmid (1992) and Sleeter (1992) reached a similar conclusion, namely, that a teacher education program cannot reform in 2 years, on average, the ideas and theories that preservice teachers bring into the program with them.

What happens when preservice teachers bring into the program a level of skill, experience, and sensibility commensurate with the level that the program expects teachers to attain at the end of the program? How might a multicultural teacher education program accommodate its students? Although there are differing opinions about the lengths of time that preservice teachers need to spend in teacher education programs, there appears to be less variation in actual lengths of programs. Might a multicultural teacher education program assess students at multiple points and then determine the need to continue in the program versus completing the program or transitioning from taking a class to teaching a class?

Out-of-School Structures. Another fault line within teacher preparation programs is the lack of attention given to out-of-school structures that influence PK-12 students. Teacher education that is multicultural prepares educators to recognize that students and their learning are not isolated from societal changes. It prepares educators to consider how shifts in the economy affect family structures and community resources and how to assist students in negotiating the incongruence between home culture and school culture.

Yet the vast majority of studies that address multicultural teacher education concentrate on classroom activity. Only a few studies comment on the impact of governmental and nongovernmental regulations on teacher education and on the relationships of multicultural teacher education to the larger social, economic, and political contexts (Cochran-Smith et al., 2004). According to Torres-Guzmán (1992), "Our schools are not equipped to understand how to educate a culturally diverse youth population that finds itself in the midst of social change and must be educated for participation in social change" (p. 488). According to Duesterberg (1998), preservice students need " "more work in identifying the power relations set up by [school] configurations' in their teaching practice" (cited in Grant et al., 2004, p. 21). How might a focus on the examination of structures that sustain inequities rather than on individual attitudes or behaviors influence educators' orientations toward multicultural education?

Teaching Practices. Much research in multicultural teacher education focuses on attitudes and perspectives of preservice teachers. We must keep in mind that attitude is not behavior. Although investigations of preservice teachers' attitudes may serve as a useful preliminary tool to gauge the effectiveness of interventions, further research must investigate the extent to which various attitudes are associated with outcomes such as greater student academic success (Bakari, 2003).

The educational literature also reports that preservice teachers who engage in multicultural education tend to use a human relations approach to the exclusion of other, more progressive approaches during their first year of teaching. The focus of the human relations approach is on helping students from different backgrounds to get along better, encouraging students to help each other and feel good about themselves, and attempting to increase school and social harmony (Grant \& Sleeter, 2003). Grant and colleagues (2004) report that in most of the 39 studies on preservice teachers (published between 1990 and 2001) that they reviewed, preservice teachers claimed to employ a human relations approach. Similarly, Ríos and Montecinos (1999) conducted a study of prospective teachers from diverse nonEuropean ethnic backgrounds and found that although 20 of them initially endorsed education that is multicultural and social reconstructionist, only 4 chose this approach when considering how they might address school problems such as curricular tracking. In addition, the use of a conservative approach to multicultural education seems to carry over once preservice teachers receive their teaching licenses and their own classrooms. Fuller (1994) studied 26 recent graduates of a teacher education program with a "social reconstructionist" perspective and concluded that the "monocultural" graduates did not demonstrate "culturally informed" teaching during their first year. 
The human relations approach (attitudes) is a problem when one uses it in isolation from other approaches. The reliance of teacher preparation programs on only a human relations approach limits preservice teachers' exposure to other approaches and ultimately the opportunity to see the approaches integrated. The isolated use of the human relations approach does little to challenge the status quo and correct injustices that education perpetuates (e.g., tracking or bias in testing). Beginning teachers and multicultural educators are typically at a disadvantage with the use of multiple approaches because they do not usually have school or community support in place, tenure, or credibility that comes with the reputation of being effective teachers. Ironically, the teaching shortage can offer multicultural teachers who openly challenge the status quo a bit of security when there are not other teachers who are readily available to fill their positions if they lose their jobs. Still, beginning teachers may feel pressured to refrain from using multicultural approaches due to risks (e.g., being outcast, fired). According to García (1997), "Agency for change through social justice requires courageous actions and strength of will in the pursuit of justice. It involves passion or anger, assertiveness, and endurance" (p. 247). We suggest that teachers who intend to combat injustices through education must learn to strategize, subvert, and choose their battles wisely. Thus, researchers must conduct research accordingly.

\section{Fault Lines in Teacher Education Programs}

A major fault line within teacher preparation programs involves those who educate preservice teachers, namely, teacher educators. What are the teacher educators' backgrounds, experiences, and understandings of multicultural education? Do the teacher educators have teaching experience and training in multicultural education? The majority of the teacher educators are middle-class, heterosexual, nondisabled, white male and female college graduates who have limited, if any, formal training in multicultural education and whose research and scholarship pay little attention to multicultural education. The research and demographic profile of the corps of teacher educators suggest a lack of diversity across the aforementioned aspects of difference and inexperience in navigating their lives across multiple and intersecting differences. Furthermore, they lack experience in learning and teaching the use of an approach (multicultural) that considers (rather than ignores) the potential for understanding that differences and/or identity positions might instigate. Therefore, few preservice teachers receive a multicultural education. Some of the current teacher educators are the first graduate students of the first generation of multicultural scholars. Because the first generation of multicultural scholars was small (approximately 200 teaching in the 1,200 teacher education programs), the chances of having one of these scholars as an instructor are slim at best.

To understand this rupture in teacher preparation in detail is to realize that even if a preservice teacher does have a multicultural educator, the preservice teacher is probably isolated when attempting to be a multicultural educator. He or she may work in an environment with little collegial support for multicultural education. When we discussed the initial findings that went into preparing this essay at the 2004 annual conference of the National Association of Multicultural Education, several faculty members from across the nation (many of whom are just beginning to teach) reported that they are often assigned to teach large undergraduate classes where students are overly resistant to multicultural education. Many reported that their attempts to help students learn about multicultural education often result in poor teaching evaluations. Chizhik (2003) reports similar reactions. Such an experience, they argue, leads to burnout, the decision to discontinue teaching multicultural education, and ultimately a reduced possibility that these scholars will gain the experience that could lead to improved outcomes or additional research in multicultural education.

Whereas studies conducted by teacher educators offer a firsthand account of the challenges and obstacles that teacher educators face in the classroom, they also reveal how even those teaching and researching in the field of multicultural teacher education can work against what they claim to work toward, namely, the 
preparation of multicultural teachers. Gay (1995) states,

Multicultural teacher education theory-practice disparity is not so surprising given that in general the development of multicultural theory has far outstripped the development of multicultural practice, with refinements of theory depending more on proposals for what should be than on conceptualizing the lessons learned from what has been. (cited in Cochran-Smith et al., 2004, p. 954)

\section{Fault Lines in Multicultural Teacher Education Research}

There are several fault lines that arise before researchers even begin to generate data: focus on preservice or novice teachers, lack of attention given to diversity within groups, and the consideration of multiple variables and how they compose the (con)text. In multicultural teacher education and research, there is a focus on preservice teachers rather than a balanced research agenda that would include teachers who have been teaching for a number of years.

Focus on Preservice or Novice Teachers. Although several studies follow teachers into the classrooms for up to 2 years following their completion of teacher preparation programs, these studies reveal very little about how multicultural education influences teachers' practice over time or how multicultural educators develop their pedagogical practice over time. We were not able to locate any long-term studies of multicultural teacher educators that follow their practice beyond their fifth year of teaching, that is, as they advance from the novice period to the tenured period.

As Wallace $(2000)$ describes, there are two categories into which teacher educators may be grouped: (1) those who are well versed in multicultural training and (2) those who are relatively new to multicultural training. Obtaining baseline data on preservice teachers' understanding of multicultural education would help to reveal the complexity of preservice teachers' resistance, acceptance, and growth in understanding the philosophy and practices of multicultural education. Longitudinal studies that examine how teachers continue their personal multicultural education training throughout their careers outside of or alongside inservice training may provide insights into how multicultural educators sustain their multicultural focus and use the knowledge and skills they have acquired to see subtle yet transformative acts of multicultural education, whether readily observable or embedded in practice.

"Latinos" in da House! Diversity Within "Cultural Groups." The Latina/o population in the United States grew by $57 \%$ from 1990 to 2000 (U.S. Census Bureau, 2001). This growing population promises to continue the problematization, both intentionally and unintentionally, of the rigid boundaries and prominence of race and/or ethnicity on which many studies in multicultural education rely. For example, $42 \%$ of Hispanics in the 2000 U.S. census chose "some other race" instead of one race or a combination of the five categories provided: white, black, Asian, American Indian/Alaska Native, or Hawaiian/Pacific Islander (Swarns, 2004). What is unique but not exclusive to this cultural group (writ large) is how their relationships to predominant racial categories vary across Latina/o communities (Wijeyesinghe \& Jackson, 2001). The title of Swarns's New York Times article, "Hispanics Resist Racial Grouping by Census," reflects a growing trend of a growing population.

Montecinos (2004) argues that in positioning teachers as ethnic-less, multicultural teacher education undermines some of the basic principles of multicultural education. For example, neglecting ethnicity casts Latinas/os as a monolithic group instead of as a complex and multifaceted peoples who may choose to identify as Latina/o, Hispano/ic, Chicana/o, Afro-Latina/o, Afro-Caribbean, and so on (or none of these) and from which we might learn new ways of orienting ourselves in the world as and/or among others.

Although discussions of Latina/o identity will not, and should not, move researchers away from ethnicity, they may influence researchers to consider the intersectionality of cultural aspects such as language, religion, and nationality and also move researchers beyond either/or black/white and white/color binaries of race. However, multiethnic and/or multiracial cultural groups such as Latinas/os, Asian Americans, 
and Cape Verdeans are not isolated from the influence of the social constructions of caste, race, gender, and sexuality or from the internalization of "-ism's" and phobias. Given this, the unchanging profile of the teaching force, and the history of the public school system's failure to educate a diverse population, attention is needed to the question of how a more diverse (including and beyond race and/or ethnicity) teaching force might influence the educational system to serve students across the artificial boundaries of perceived differences.

Growth in the population of individuals who willingly and/or unwillingly identify or are identified as Latina/o may inspire researchers in multicultural (teacher) education to ask different questions. For instance, how can teacher education programs recruit and prepare more Latina/o and non-Latina/o preservice teachers? How can we modify the educational system to benefit students from the Latinalo diaspora with a transnational identity, splitting their time between their home country and the United States of (North) America (not Mexico)? How will the anticipated demographic shift toward a majority population of people who can trace their ancestry to Spanish-speaking forebears affect our conceptualization of the Americas? Will we come to view the United States as part of a broader America, that is, as part of rather than separate from Latin America? What educational outcomes will serve our students as territorial borders shift, dissolve, or widen?

Crossing at the Intersections: Transitory Identities. Too few studies have addressed intersecting attributes and aspects of identity or culture (Grant et al., 2004). Even when researchers describe themselves and the subjects of their studies, they tend to discuss their race and/or ethnic backgrounds to the exclusion of other attributes or aspects of their identity. When they discuss other attributes, their discussions are still limited to gender, class, and language (Brandon, 2003). Conceptions of identity as fluid, shifting, or transitory (e.g., hybridity [Bhabha, 1994]; border crossing [Anzaldúa, 1987]; cyborg [Haraway, 1991]) receive little attention in multicultural teacher education. Within these conceptions of identity is an element of strategic negotiation and transgression, unlike the static and essentialized conceptions of identity present in much of the multicultural teacher education research. Furthermore, studies in multicultural education that refer to identities in transitory terms tend to limit their analysis to the identity or culture of the teacher, not the students. Where studies refer to transitory identities, they fail to examine how teachers' hybrid identities, for example, might shape their practice (e.g., Ladson-Billings \& Henry, 1990; Wortham \& Contreras, 2002). In neglecting to analyze transitory and multiple identities, researchers miss an opportunity to understand how teachers or students might imitate or create alternative behaviors with the intention of developing a repertoire of teaching performances. Would our teaching force reinvent itself given the expectation that teachers can and should perform multiple identities at will?

Perhaps this gap in the research of teachers' transitory identities is in part reflective of the "limited empirical evidence linking age and ethnic identity achievement," especially for individuals over 21 years of age (Ontai-Grzebik \& Raffaelli, 2004, p. 562). Within this statement are several assumptions that contrast the idea of continuous (transitory/shifting/fluid) identity (re)development and that are worth pursuing before researchers embark on investigating the link between, for example, age and ethnic identity achievement. These assumptions are that development of a stable identity position is an achievement, identity (re)development comes with age rather than through various factors that have little to do with age, and identity development is a series of stages that culminate in adulthood rather than a lifelong series of processes.

Instead, we might understand identity (re)development as a broad spectrum of behaviors or conditions rather than automatically relegating it to the extreme designation of identity crises. At least, we should question how our investment in stability and order (as evident in research and educational practices in general) expands and/or limits our expectations of teachers, students, and teacher educators. Haberman (1991) argues that prospective teachers who are engaged in developing their own identities constitute a weakness in teacher reform. On the contrary, we suggest that 
teachers' engagement in identity development may be beneficial. We suggest that there is a great difference between engagement and consumption. In addition, Haberman suggests that mature people with diverse life and work experience may be better suited to address the serious challenges facing youth such as poverty and racism. Rather than read Haberman's two statements as built on one another, we separate his suggestion that experience is a teaching asset from his argument that recruiting and training teachers undergoing identity development is a weakness in teacher education. We suggest that multicultural teacher education would benefit from recruiting and training teachers who have a broad range of experiences as well as the ability to consider, engage, and (re)develop their own identities.

Multicultural teachers draw on components of students' (sub)cultures as well as intersecting aspects of identity. At the same time, they recognize that students function as individuals with varying degrees of membership in social groups and in response to multiple influences. Future research in multicultural teacher education should consider the intersectionalities of attributes and aspects of identity as entry points from which we position ourselves as educators, students, and researchers in the process of understanding how concurring acts of negotiation among intervening factors of power, economy, politics, time, and history influence the decisions that educators, students, and researchers make. These fuzzy areas-the borders around categories-can trouble our research and our thinking about who teachers and students are and who they become in the moments they negotiate the terrains of their classrooms.

Revealing how attributes of identity, aspects of culture, and social factors intersect and become prominent at different times in different ways with different consequences for different students makes it difficult for educators and researchers to rely too much on static descriptions of students. This complexity most accurately reflects the daily classroom. Those who aspire to become educators will take from this an understanding that teaching, learning, and producing quality research are not simple practices. When multiple and intersecting aspects of identity are considered (e.g., race, ethnicity, sexuality, class, gender, religion/spirituality, age, (dis)ability, language) alongside notions of fluidity, hybridity, intragroup variability, and social factors, one begins to see how daunting a task it would be to prepare "types" of teachers to work with "types" of students. Rather than preparing teachers how to teach particular groups of students (them), we might begin to envision teacher education as preparing society to teach "multiculturally." To teach multiculturally involves engaging in a continual process in relation to other processes (e.g., culture).

Hidden in (the Con)Texts. According to Trueba and Wright (1992),

Context is a dynamic, interactional notion and is understood as a determinant of human behavior. The context of classroom interactions is not a static set of situations devoid of persons interacting or the physical and human surroundings alone. Context consists primarily of individuals interacting and, by their interaction, defining the function and meaning of an interactional event. More specifically, a context is constituted by an accumulation of linguistic, paralinguistic, and kinesic features and proxemic shifts. (pp. 327-328)

Are particular settings conducive to the maintenance of unequal power relations, professionalism, and formal authority? Can we open avenues for multicultural education and research by changing the setting and the focus of our observations? In multicultural teacher education research, there is not much variation in the contexts in which preservice teachers are prepared. Moreover, the researched experiences of classroom teachers are often limited to the classroom. Physical contexts that multicultural researchers and educators seldom explore are workshops, computer labs, and academic club meetings. Perhaps these contexts are more culturally compatible or conducive to the use of (multi)culturally relevant pedagogy. Few studies in the literature on multicultural education examine how intangible factors structure learning experiences (e.g., the structure and use of time) and how their alteration might positively affect the educational experiences for a broader range of students. 
Future research in multicultural education and teacher education programs might consider how switching (con)texts can alter the dimensions and dynamics of the social, epistemological, and power structures to shape the learning environment. Linking the investigation of classroom practice to, for instance, the structures of time and space that govern classroom choices, both directly and indirectly, will move multicultural teacher education research toward new questions. For instance, the theme of sociospatiotemporality surfaces in Wortham and Contreras's (2002) observation of a bilingual classroom. The teacher in this study adjusted the socio-spatiotemporal structures of the classroom to reflect the learning styles and social patterns of her Spanish-speaking students. González (2002) outlines three cultural systems in a discussion of campus climate: (1) the social world, (2) the physical world, and (3) the epistemological world. Such an analysis reveals how one's opportunities for learning extend beyond the social and how the social is dimensional. González considers how physical structures, as part of the campus climate, shaped Chicana/o students' college experience. According to Grant and colleagues (2004), there continues to be a lack of research into the physical environments of schools.

In addition, "attempts to identify best practices for multicultural teacher education need to consider the impact of multiple social dimensions" (Montecinos, 2004, p. 168). To use a person-centered, experiential, and relational way of thinking about researching and writing about the everyday experience of multiculturalism or "narrative multiculturalism," Phillion (2002) suggests that researchers immerse themselves in the classroom so as to experience and absorb the "patterns" and "rhythms" of the classroom life and be more experiential than theoretical. As Phillion reports, "I learned to be more present with Pam [the teacher], more like a sponge, soaking up what was around me" (p. 272). Socialization occurred between the researcher and students as well. Phillion writes, "As I interacted with Pam and her students, my traditional notions of what was best for immigrant and minority children were shattered" (p. 275). Multicultural education is in part about socialization, yet researchers seldom consider how interactions among educators contribute to their practice as multicultural educators.

Multicultural educators and researchers should seek to understand how people get along in the world as they experience it and how the dimensions and facets of life become more or less pronounced within changing (con)texts and resources such as time and space. Multicultural teacher education and research can benefit from studies that acknowledge and reflect the complexities and challenges involved in the preparation of the next generation of educators. These educators will likely encounter within their classrooms and throughout their workdays diverse household arrangements, parental ages, socially acceptable lifestyles, cross-cultural alliances, and students who might describe themselves by using words with varying prefixes such as multilinguistic, intersex, and transnational. Regardless of students' attitudes, classes, identities, and cultures, there is a common goal that should guide teachers, teacher educators, and teacher training programs, namely, that all teachers should know "various procedures they can use to acquaint themselves with the specific students in their future classes" (Zeichner et al., 1998, p. 167). "Above all, they should know how to utilize the surroundings, physical and social, that exist so as to extract from them all they have to contribute to building up experiences that are worthwhile" (Parkay, 1983, p. 209). "Multicultural teacher education programs should therefore assist prospective teachers to develop a repertoire of instructional approaches that include skills in direct instruction, inquiry methods, and cooperative learning (e.g., group projects, peer centers, reciprocal teaching)" (Villegas, 1991, cited in Zeichner et al., 1998, p. 168).

\section{Promoting Praxis:}

\section{A RESEARCH-INFORMED VISION}

A common concern evident throughout the research is how to reflect in practice what is anchored in theory. For example, how do we educate across diversity using differences as contributors to success? Whether one is teaching preservice teachers, reporting research findings, designing research, or posing questions, 
scholars need some vision of good practice. In the Multicultural Preservice Teacher Education Project, Zeichner and colleagues (1998) outline a vision of good practice. The design principles are organized into three main categories that emphasize issues of (1) institutional and programmatic reform, (2) personnel (staff and students), and (3) curriculum and instruction in teacher education programs. As a whole, these principles offer a lens through which researchers can analyze research and teaching in multicultural teacher education. These design principles are not prescriptive or formulaic; rather, they serve as a guide that provides educators at all levels with a means to self-check and activate warning signs while developing a common language from which educators can join forces. Mysteriously, as of October 2004, Zeichner and colleagues' article had been cited in only 11 subsequent articles.

The design principles are as follows:

1. The mission, policies, and procedures of the institution reflect the values of diversity and multicultural education.

2. The institution is committed to multicultural teacher education.

3. The teacher education program is a living example of multicultural education.

4. Admissions requirements to the teacher education program include multicultural criteria as well as academic criteria.

5. Faculty, staff, and supervisors are committed to and competent in multicultural teacher education.

6. Multicultural perspectives permeate the entire teacher education curriculum, including general education courses and those in academic subject matter areas.

7. The program fosters the understanding that teaching and learning occur in sociopolitical contexts that are not neutral but rather are based on relations of power and privilege.

8. The program is based on the assumption that all students in elementary and secondary schools bring knowledge, skills, and experiences that should be used as resources in teaching and learning and that high expectations for learning are held for all students.

9. The program teaches prospective teachers how to learn about students, families, and communities as well as how to use knowledge of culturally diverse students' backgrounds in planning, delivering, and evaluating instruction.

10. The program helps prospective teachers to reexamine their own and others' multiple and interrelated identities.

11. The program provides carefully planned and varied field experiences that explore sociocultural diversity in schools and communities.

12. The program helps prospective teachers to develop the commitment to be change agents who work to promote greater equity and social justice in schooling and society.

13. The program teaches prospective teachers how to change power and privilege in multicultural classrooms.

14. The program draws on and validates multiple types and sources of knowledge.

The process of outlining these principles involved a collaborative process of multiple steps that included a literature review, peer evaluation, public presentation, and feedback. This process aligns with the 14th principle of Zeichner and colleagues (1998), which emphasizes drawing on and validating multiple types and sources of knowledge. For the same reason why Abt-Perkins, Hauschildt, and Dale (2000) suggest that multicultural supervisors should collaborate, so should researchers. Research conducted by partners or teams fosters socialization and allows for the filter of differing, similar, and common opinions/perspectives. Abt-Perkins and colleagues emphasize the importance of collaboration in studies of supervision practices. They state, "Only such conversations will allow us to find our blind spots and silences" (p. 47).

The challenges and obstacles in conducting research are similar to those affecting the preparation of multicultural educators. The (over)use of a (narrow) demographic rationale, the 
overuse and isolated use of a human relations approach, the avoidance of the structural (including power relations and their effects), and the use of a narrow lens to observe multicultural education are some of the fault lines that work against the preparation of multicultural educators and ultimately their formation into a critical mass. In what direction might other rationales and subsequent lines of inquiry lead multicultural teacher education? How long will the education community continue to face the challenges of preparing multicultural educators before co-optation, for example, makes it unfashionable and/or unprofitable? Finally, how long will society permit this question to remain an enduring unresolved problem?

\section{Crossing Into the NeXt Moment}

To be sure, assessing multicultural education requires longer periods of observation across time in place of the periodic and episodic observations that generally feed our understanding of what teacher educators and their preservice teachers are doing in classrooms. In addition to asking whether someone is, or is not, practicing multicultural education, we might ask the question: To what extent? This question does not require an either/or response. In contrast, the question allows multicultural educators and researchers to assess their practice, for instance, in terms of the depth and breadth with which they demonstrate an integrated approach to multicultural education and the extent to which their multicultural practice is evident throughout time and their spheres of influence.

Multicultural education proposes that we examine what is invisible, covert, hidden, embedded, and often entangled in the obvious such as the identifiers we impose or reinscribe (e.g., Latina/o, people of color, white, (dis)abled, female). It asks that we look deeply and broadly at lives and learning environments and speak of their complexities, multiple factors, and subject-object positions and, at the same time, question what, how, and why we see and speak what we do. Instances of researchers examining cross-/intercultural, -ethnic, and -racial relations may increase as the borders of single-group affiliation, social constructions, disciplines, and geographic regions become porous and blur. Likewise, discussions of cultural groups should include the multiple ways in which members of groups align and realign over time given any number of intervening, imposing, and/or influencing conditions.

Multicultural teachers and educators should strive for robust images of "students" and "teachers" (images they intend to create or imitate for themselves or to locate in others). Furthermore, educators and researchers should integrate and incorporate multicultural education into their lives as a way of learning or understanding the world. An understanding of teaching recognizes that teaching involves continuous negotiation among intervening factors. Understanding teaching as a complex endeavor can offer a richer (con)text for preparing multicultural educators and researching multicultural teacher education. According to Grant and Zozakiewicz (1995), "It is essential that student teachers come to conceive of multicultural education as an integral and embedded part of teaching and schools; every decision, action, assignment, organizational structure, and communicative act works either toward or against the goals of multicultural education" (p. 272). Multicultural teachers, educators, and researchers must learn to recognize multicultural education in practice. This includes being able to analyze the hidden curriculum for its presence as well as the presence of the inequitable practices that it challenges. Assessing multicultural educators requires assessors for whom the lens of multicultural education is wide and telescopic.

Perhaps some educators and researchers have a limited understanding of multicultural education and its nuances. Multicultural education in practice may be grossly underrepresented in the research. Even if there are failed attempts to capture and represent in the research instances of multicultural practice, we suggest that these failed attempts are not commonplace. The teacher educators' reports of resistance among incoming preservice teachers signal that multicultural education - as a philosophy or practice (if provided) - is not internalized, embraced, or understood by preservice teachers during their PK -12 schooling. Doubts over representation call attention to the responsibility of researchers 
to capture and report multicultural education in practice-even when multicultural education is not the focus. Research of this kind not only will offer a truer estimate of multicultural education and educators but also will help us to understand that such practice is possible, that certain conditions make such practice possible, and that the practice and its conditions are directly and indirectly observable. These revelations move us closer to asking how.

If we submit that multicultural teacher education derives from multicultural education, then it is reasonable to suggest that the research that drives both of them should also reflect the principles of multicultural education. Researchers in the field should also analyze how they, as cultural beings operating within structures and social relations that govern their possibilities, are implicated within their studies and ultimately affect the training, preparation, and knowledge base of teacher educators, as well as preservice and inservice teachers. Researchers should also have a complex model for interrogating their practice. According to Denzin and Lincoln (2000), we are crossing into the seventh moment in social science:

In the seventh moment, the means (methods) of social science are developed, refined, and cherished for their contributions to communities characterized by respectful and loving difference, social justice, and equal access to material, social, educational, and cultural capital (the ends of ethnography). (p. 1062)

The direction of social science research, as described by Denzin and Lincoln (2000) in the preceding excerpt, aligns ideologically with the philosophy of multicultural education. That is, researchers have available multiple strategies of inquiry and perspectives that are congruent with the aims of multicultural teacher education. Multiple strategies may be exactly what we need to help us chase the moving targets of cultural competency or cultural literacy. In part "because teachers have no alternative but to be responsive to the human world, a world continuously marked by change," the task of articulating the nature of teaching is ongoing (Hansen, 2004 , p. 142). Regardless of the strategies chosen, may our actions be in combination with "cultural humility" (S. Kapani, personal communication, October 29, 2004) while keeping in mind that multicultural education is for everyone or no one.

\section{REFERENCES}

Abt-Perkins, D., Hauschildt, P., \& Dale, H. (2000). Becoming multicultural supervisors: Lessons from a collaborative field study. Journal of Curriculum and Supervision, 16(1), 28-47.

American Association of Colleges for Teacher Education. (1990). AACTE/Metropolitan Life Survey of Teacher Education Students. Washington, DC: Author.

Anzaldúa, G. (1987). Borderlands/La frontera: The new mestiza. San Francisco: Aunt Lute Books.

Bakari, R. (2003). Preservice teachers' attitudes toward teaching African American students: Contemporary research. Urban Education, 38, 640-654.

Banks, J. (1993). Approaches to multicultural curriculum reform. In J. Banks \& C. A. M. Banks (Eds.), Multicultural education: Issues and perspectives (2nd ed., pp. 195-214). Boston: Allyn \& Bacon.

Banks, J. A., \& Banks, C. A. (Eds.). (1995). Handbook of research on multicultural education. New York: Macmillan.

Bhabha, H. K. (1994). The location of culture. New York: Routledge.

Brandon, W. W. (2003). Toward a white teacher's guide to playing fair: Exploring the cultural politics of multicultural teaching. Qualitative Studies in Education, 16(1), 31-50.

Chizhik, E. W. (2003). Reflecting on the challenges of preparing suburban teachers for urban schools. Education in Urban Society, 35, 443-461.

Cochran-Smith, M., Davis, D., \& Fries, K. (2004). Multicultural teacher education: Research, practice, and policy. In J. Banks \& C. A. McGeeBanks (Eds.), Handbook of research on multicultural education (2nd ed., pp. 931-975). San Francisco: Jossey-Bass.

Denzin, N. K., \& Lincoln, Y. S. (2000). Handbook of qualitative research ( 2 nd ed.). Thousand Oaks, CA: Sage.

Duesterberg, L. (1998). Rethinking culture in the pedagogy and practices of preservice teachers. Teaching and Teacher Education, 14, 497-512. 
Flores, M. A. (2001). Person and context in becoming a new teacher. Journal of Education for Teaching, 27, 135-148.

Frazier, L. (1977). The multicultural facet of education. Journal of Research and Development in Education, 11, 10-16.

Fuller, M. L. (1992). Teacher education programs and increasing minority school populations: An educational mismatch? In C. A. Grant (Ed.), Research and multicultural education: From the margins to the mainstream (pp. 184-200). Washington, DC: Falmer.

Fuller, M. L. (1994). The monocultural graduate in the multicultural environment: A challenge for teacher educators. Journal of Teacher Education, 45, 269-277.

García, R. L. (1982). Teaching in a pluralistic society: Concepts, models, strategies. New York: Harper \& Row.

García, S. S. (1997). Social justice. In C. A. Grant \& G. Ladson-Billings (Eds.), Dictionary of multicultural education. Phoenix, AZ: Oryx.

Gay, G. (1995). Curriculum theory and multicultural education. In J. A. Banks \& C. A. McGee-Banks (Eds.), Handbook of research on multicultural education (pp. 25-43). New York: Macmillan.

Gay, G., Dingus, J. E., \& Jackson, C. (2003). The presence and performance of teachers of color in the profession. Available: www.communityteachers.org

Giroux, H. A. (1996). Fugitive cultures: Race, violence, and youth. New York: Routledge.

Gollnick, D. (1992). Multicultural education: Policies and practices in teacher education. In C. A. Grant (Ed.), Research and multicultural education (pp. 218-239). Washington, DC: Falmer.

Gomez, M. L. (1993). Prospective teachers' perspectives on teaching diverse children: A review with implications for teacher education and practice. Journal of Negro Education, 62, 459-474.

Gomez, M. L., \& Tabachnick, B. R. (1992). Telling teaching stories. Teaching Education, 4, 129-138.

González, K. P. (2002). Campus culture and the experiences of Chicano students in a predominantly white university. Urban Education, 37, 193-218.

Grant, C. A. (1977). Multicultural education: Commitments, issues, and applications. Washington, DC: Association for Supervision and Curriculum Development.
Grant, C. A., Elsbree, R. A., \& Fondrie, S. (2004). A decade of research on the changing terrain of multicultural research. In J. A. Banks \& C. A. McGee-Banks (Eds.), Handbook of multicultural education (2nd ed., pp. 1-70). San Francisco: Jossey-Bass.

Grant, C. A., \& Millar, S. (1992). Research and multicultural education: Barriers, needs, and boundaries. In C. A. Grant (Ed.), Research and multicultural education: From the margins to the mainstream (pp. 7-18). London: Falmer.

Grant, C. A., \& Secada, W. G. (1990). Preparing teachers for diversity. In W. R. Houston (Ed.), Handbook of research on teacher education: $A$ project of the Association of Teacher Educators (pp. 403-422). New York: Macmillan.

Grant, C. A., \& Sleeter, C. E. (2003). Turning on learning: Five approaches to multicultural teaching plans for race, class, gender, and disability (3rd ed.). New York: John Wiley.

Grant, C. A., \& Zozakiewicz, C. A. (1995). Student teachers, cooperating teachers, and supervisors: Interrupting the multicultural silences of student teaching. In J. M. Larkin \& C. E. Sleeter (Eds.), Developing multicultural teacher education curricula (pp. 259-278). New York: State University of New York Press.

Growe, R., Schmersahl, K., Perry, R., \& Henry, R. (2002). A knowledge base for cultural diversity in administrator training. Journal of Instructional Psychology, 29, 205-212.

Haberman, M. (1991). The rationale for training adults as teachers. In C. E. Sleeter (Ed.), Empowerment through multicultural education (pp. 275 286). Albany: State University of New York Press.

Hansen, D. T. (2004). A poetics of teaching, Educational Theory, 54(2), 119-142.

Haraway, D. (1991). Simians, cyborgs, and women: The reinvention of nature. New York: Routledge.

Ladson-Billings, G. (1999). Preparing teachers for diverse student populations: A critical race theory perspective. In A. Iran-Nejad \& D. Pearson (Eds.), Review of research in education (Vol. 24, pp. 211-248). Washington, DC: American Educational Research Association.

Ladson-Billings, G. (2001). Crossing over to Canaan: The journey of new teachers in diverse classrooms. San Francisco: Jossey-Bass.

Ladson-Billings, G., \& Henry, A. (1990). Blurring the borders: Voices of African liberatory pedagogy 
in the United States and Canada. Journal of Education, 172(2), 72-88.

Macedo, S. (2000). Diversity and distrust: Civic education in a multicultural democracy. Cambridge, MA: Harvard University Press.

Martin, R. J. (Ed.). (1995). Practicing what we teach: Confronting diversity in teacher education. Albany: State University of New York Press.

McDiarmid, G. W. (1992). What to do about differences? A study of multicultural education for teacher trainees in the Los Angeles Unified School District. Journal of Teacher Education, 43(2), 83-93.

Montecinos, C. (2004). Paradoxes in multicultural teacher education research: Students of color positioned as objects while ignored as subjects. International Journal of Qualitative Studies in Education, 17(2), 167-181.

National Council for Accreditation of Teacher Educators. (2002). Professional Standards for the Accreditation of Schools, Colleges, and Departments of Education. Available: www .ncate.org/2000/unit_stnds_2002.pdf

Oliva, M., \& Staudt, K. (2003). Pathways to teaching: Latino student choice and professional identity development in a teacher training magnet program. Equity \& Excellence, 36, 270-279.

Ontai-Grzebik, L. L., \& Raffaelli, M. (2004). Individual and social influences on ethnic identity among Latino young adults. Journal of Adolescent Research, 19, 550-575.

Parkay, F. W. (1983). White teacher, black school: The professional growth of ghetto teacher. New York: Praeger.

Parrillo, V. (1996). Diversity in America. Thousand Oaks, CA: Pine Forge.

Pataniczek, D., \& Isaacson, N. (1981). The relationship of socialization and the concerns of beginning secondary teachers. Joumal of Teacher Education, 32(3), 14-17.

Pearl, A. (1997). Democratic education as an alternative to deficit thinking. In R. R. Valencia (Ed.), The evolution of deficit thinking (pp. 211-241). London: Falmer.

Phillion, J. (2002). Narrative multiculturalism, Journal of Curriculum Studies, 34, 265-279.

Ríos, F., \& Montecinos, C. (1999). Advocating social justice and cultural affirmation: Ethnically diverse preservice teachers' perspectives on multicultural education. Equity and Education, $32(3), 66-76$.
Risk, R. C. (2000). Student social class and teacher expectations: The self-fulfilling prophecy in ghetto education. Harvard Educational Review, $70,266-301$. (Original work published in 1970)

Sacks, J. (2002). The dignity of difference: How to avoid the clash of civilizations. London: Continuum.

Sleeter, C. E. (1992). Restructuring schools for multicultural education. Journal of Teacher Education, 43(2), 141-148.

Swarns, R. L. (2004, October 24). Hispanics resist racial grouping by census. The New York Times. Available: www.nytimes.com/2004/10/24/ national/ 24census.html

Torres-Guzmán, M. E. (1992). Stories of hope in the midst of despair: Culturally responsive education for Latino students in an alternative high school in New York City. In M. Saravia-Shore \& S. F. Arvizu (Eds.), Cross-cultural literacy: Ethnographies of communication in multiethnic classrooms (pp. 477-490). New York: Garland.

Trueba, H. T., \& Wright, P. G. (1992). On ethnographic studies and multicultural education. In M. Saravia-Shore \& S. F. Arvizu (Eds.), Crosscultural literacy: Ethnographies of communication in multiethnic classrooms (pp. 299-490). New York: Garland.

U.S. Census Bureau. (2001). Hispanic population in the United States: Current population reports, population characteristics. Washington, DC: Government Printing Office. Available: www .census.gov/population/cen2000/phc-t1/tab04.pdf

Villegas, A. M. (1991). Culturally responsive pedagogy for the 1990's and beyond. Princeton, NJ: Educational Testing Service.

Villegas, A. M., \& Clewell, B. C. (1998). Increasing teacher diversity by tapping the paraprofessional pool. Theory Into Practice, 37(2), 121-130.

Wallace, B. C. (2000). Call for change in multicultural training at graduate schools of education: Educating to end oppression and for social change. Teachers College Record, 102, 1086-1111.

Wijeyesinghe, C. L., \& Jackson, B. W. (2001). New perspectives on racial identity development: A theoretical and practical anthology. New York: New York University Press.

Wortham, S., \& Contreras, M. (2002). Struggling toward culturally relevant pedagogy in the Latino diaspora. Journal of Latinos and Education, 1(2), 133-144. 
Young, I. M. (1990). Justice and the politics of difference. Princeton, NJ: Princeton University Press.

Zeichner, K. M., \& Gore, J. M. (1990). Teacher socialization. In W. R. Houston (Ed.), Handbook of research in teacher education (pp. 329-348). New York: Macmillan.

Zeichner, K. M., Grant, C., Gay, G., Gillette, M., Valli, L., \& Villegas, A. M. (1998). A research informed vision of good practice in multicultural teacher education: Design principles. Theory Into Practice, 37(2), 163-171.

Zeichner, K. M., \& Hoeft, K. (1996). Teacher socialization for cultural diversity. In J. Sikula, T. J. Buttery, \& E. Guyton (Eds.), Handbook on teacher education: A project of the Association of Teacher Educators (2nd ed., pp. 525-547). New York: Simon \& Schuster.

\section{FuRTHER READING}

Ball, A. (2000). Empowering pedagogies that enhance the learning of multicultural students. Teachers College Record, 102, 1006-1034.

Banks, J. A., \& Banks, C. A. (1993). Multicultural education: Issues and perspectives (2nd ed.). Boston: Allyn \& Bacon.

Banks, J. A., \& Banks, C. A. (Eds.). (2004). Handbook of research on multicultural education (2nd ed.). San Francisco: Jossey-Bass.

Bennett, C. (2001). Genres of research in multicultural education. Review of Educational Research, $71(2), 171-217$.

Britzman, D. (1991). Practice makes practice: A critical study of learning to teach. Albany: State University of New York Press.

Cochran-Smith, M. (1991). Learning to teach against the grain. Harvard Educational Review, 61, 279-310.

Cockrell, K. S., Placier, P. L., Cockrell, D. H., \& Middleton, J. N. (1999). Coming to terms with "diversity" and "multiculturalism" in teacher education: Learning about our students, changing our practice. Teaching and Teacher Education, 15, 351-366.

Ellis, C. (2004). The ethnographic I: A methodological novel about autoethnography. Walnut Creek, CA: AltaMira.

Garmon, M. A. (2004). Changing preservice teachers' attitudes/beliefs about diversity: What are the critical factors? Journal of Teacher Education, 55, 201-213.
Gay, G. (2004). Curriculum theory and multicultural education. In J. A. Banks \& C. A. Banks (Eds.), Handbook of research on multicultural education (2nd ed., pp. 25-43). San Francisco: Jossey-Bass.

Grant, C. A., \& Ladson-Billings, G. (Eds.). (1997). Dictionary of multicultural education. Phoenix, AZ: Oryx.

Growe, R., Schmersahl, K., Perry, R., \& Henry, R. (2002). A knowledge base for cultural diversity in administrator training. Journal of Instructional Psychology, 29, 205-212.

Hidalgo, N. M., Siu, S., \& Epstein, J. L. (2004). Research on families, schools, and communities: A multicultural perspective. In J. A. Banks \& C. A. McGee-Banks (Eds.), Handbook of research on multicultural education (2nd ed., pp. 631655). San Francisco: Jossey-Bass.

Jennings, L. B., \& Smith, C. P. (2002). Examining the roles of critical inquiry for transformative practices: Two joint case studies of multicultural education. Teachers College Record, 104, 456-481.

Kiang, P. N. (2004). Linking strategies and interventions in Asian American Studies to K-12 classrooms and teacher preparation. International Journal of Qualitative Studies in Education, 17, 199-225.

Ladson-Billings, G. (1995). But that's just good teaching! The case for culturally relevant pedagogy. Theory Into Practice, 34(3), 159-165.

LeCompte, M. (2002). The transformation of ethnographic practice: Past and current challenges. Qualitative Research, 2, 283-299.

Montecinos, C. (1995). Multicultural teacher education for a culturally diverse teaching force. In R. J. Martin (Ed.), Practicing what we teach: Confronting diversity in teacher education (pp. 97116). Albany: State University of New York Press.

Nieto, S. (2000). Affirming diversity: The sociopolitical context of multicultural education (3rd ed.). New York: Longman.

Olmedo, I. M. (2004). Raising transnational issues in a multicultural curriculum project. Urban Education, 39, 241-265.

Saravia-Shore, M., \& Arvizu, S. F. (Eds.). (1992). Cross-cultural literacy: Ethnographies of communication in multiethnic classrooms. New York: Garland.

Sleeter, C. E., \& Grant, C. A. (1987). An analysis of multicultural education in the United States. Harvard Educational Review, 57, 421-444. 


\section{What Are We Tripping On? Transgressing the Fault Lines in Research • 115}

Sleeter, C. E., \& McLaren, P. (1995). Introduction: Exploring connections to build a critical multiculturalism. In C. Sleeter \& P. McLaren (Eds.), Multicultural education, critical pedagogy, and the politics of difference (pp. 5-32). Albany: State University of New York Press.

Speght, S. L., \& Vera, E. M. (2004). A social justice agenda: Ready or not? The Counseling Psychologist, 32(1), 109-118.
Valencia, R. R. (1997). The evolution of deficit thinking. London: Falmer.

Wallace, B. C. (2000). Call for change in multicultural training at graduate schools of education: Educating to end oppression and for social justice. Teachers College Record, 102, 1086-1111.

Weiner, L. (1993). Preparing teachers for urban schools: Lessons from thirty years of school reform. New York: Columbia University, Teachers College Press. 